\title{
Analisis Kesalahan Siswa dalam Menggeneralisasi Pola Linier
}

\author{
Yayan Eryk Setiawan \\ Program Studi Pendidikan Matematika, Universitas Islam Malang, Malang, Indonesia; \\ yayaneryksetiawan@unisma.ac.id
}

Info Artikel: Dikirim: 6 April 2020 ; Direvisi: 28 Juni 2020; Diterima: 16 September 2020 Cara sitasi: Setiawan, Y. E. (2020). Analisis Kesalahan Siswa dalam Menggeneralisasi Pola Linier. JNPM (Jurnal Nasional Pendidikan Matematika), 4(2), 180-194.

\begin{abstract}
Abstrak. Salah satu kemampuan penting dalam matematika adalah generalisasi. Kemampuan generalisasi pada siswa Sekolah Menengah Pertama (SMP) lebih menekankan pada generalisasi pola linier. Namun siswa masih memiliki kesulitankesulitan dalam hal ini, yang pada akhirnya menyebabkan kesalahan dalam menggeneralisasi pola linier. Melalui analisis kesalahan pekerjaan siswa dalam menyelesaikan masalah pola linier, maka penelitian ini bertujuan untuk memperoleh gambaran kesalahan siswa dalam menggeneralisasi pola linier. Jenis penelitian ini adalah penelitian kualitatif deskriptif dengan pendekatan studi kasus. Instrumen berupa soal pola linier diberikan kepada siswa. Sebanyak 4 siswa terpilih dengan karakteristik kesalahan yang berbeda sebagai subjek penelitian. Analisis kesalahan pekerjaan siswa dilakukan secara deskriptif dengan mengategorikan ke dalam dua bentuk kesalahan, yaitu overgeneralisasi dan overspesialisasi. Hasil penelitian menunjukkan bahwa kesalahan siswa berupa kesalahan overgeneralisasi adalah kesalahan terburu-buru membuat hasil generalisasi sebelum memiliki data yang cukup. Penyebab utama kesalahan ini adalah pemrosesan selektif yang hanya menggunakan tahapan tertentu dari pola linier. Sedangkan kesalahan overspesialisasi adalah kesalahan memberikan batasan yang tidak tepat dalam menggeneralisasi pola linier. Penyebab utama kesalahan ini adalah persepsi siswa yang membatasi tentang penggunaan dan makna istilah-istilah yang ada dalam pola linier. Untuk menghindari kesalahan overgeneralisasi, siswa sebaiknya melakukan pemrosesan secara berurutan dan untuk menghindari kesalahan overspesialisasi, guru dapat menjelaskan makna dari istilah-istilah yang ada dalam pola linier.
\end{abstract}

Kata Kunci: Kesalahan Generalisasi, Overgeneralisasi, Overspesialisasi, Pola Linier.

\begin{abstract}
One of the important skills in mathematics is the ability to generalize. The generalization ability of junior high school students places more emphasis on generalizing linear patterns. However, students still have difficulties in generalizing linear patterns, which turn causes errors in generalizing linear patterns. By analyzing student work errors in solving linear pattern problems, this study aims to obtain an overview of students' errors in generalizing linear patterns. This type of research is descriptive qualitative research with a case study approach. The instruments were linear pattern problems that were given to the students. A total of 4 students
\end{abstract}


wereselected with different error characteristics as research subjects. The analysis of students' errors was descriptively categorizing them into two kinds of error. There were overgeneralization and overspecialization. The results showed that students' errors in generalizing linear patterns in overgeneralization errors were mistakes in rushing to generalizations before having sufficient data. The main cause of this overgeneralization error is selective processing, which only uses specific linear patterns. Meanwhile, the overspecialization error is an error that provides fuzzy boundaries in generalizing a linear pattern. This overspecialization error's main cause is students' limiting perceptions of terms' use and meaning in a linear pattern. To avoid overgeneralization errors, students should do the processing sequentially. To avoid overspecialization errors, the teacher can explain the importance of the terms in a linear pattern.

Keywords: Generalization's Error, Linear Patterns, Overgeneralization, Overspecialization.

\section{Pendahuluan}

Salah satu kemampuan yang ditekankan dalam pembelajaran matematika adalah generalisasi. Tanişli dan Özdaş (2009) mengatakan bahwa generalisasi adalah dasar untuk mengembangkan pengetahuan matematika dan merupakan pusat kegiatan matematika. Generalisasi juga menjadi fokus utama dari standar kurikulum dan upaya penelitian dalam pendidikan matematika (Lannin, Barker, \& Townsend, 2006; Tillema \& Gatza, 2017). Generalisasi juga merupakan keterampilan dasar dalam pembelajaran matematika di berbagai topik (Chua \& Hoyles, 2014). Hal ini menyebabkan generalisasi dianggap sebagai bagian penting dari pembelajaran matematika (Hill, Lannin, \& Garderen, 2015). Lebih lanjut dapat dikatakan bahwa tindakan generalisasi adalah inti dari aktivitas matematika, karena berfungsi sebagai sarana untuk membangun pengetahuan baru (Ellis, Tillema, Lockwood, \& Moore, 2017). Generalisasi juga hal yang penting untuk mendukung berbagai topik dalam pembelajaran matematika (Setiawan, Purwanto, Parta, \& Sisworo, 2020). Jadi secara umum dapat dikatakan bahwa kemampuan generalisasi merupakan hal yang penting dalam mempelajari matematika.

Salah satu materi yang digunakan untuk membangun kemampuan generalisasi adalah pola. Hal ini didasarkan bahwa pola merupakan langkah penting untuk pembentukan generalisasi (Tanişli \& Özdaş, 2009). Selain itu, sebagian besar tugas matematika yang digunakan oleh para peneliti untuk mengetahui kemampuan generalisasi adalah pola, baik secara numerik maupun secara geometris (Jureczko,_2017). Pola merupakan konsep kunci untuk memahami pengetahuan dan konsep dalam matematika (Tanişli \& Özdaş, 2009). Bekerja dengan pola dapat muncul dalam berbagai konteks dan 
berkonstribusi terhadap pengembangan beberapa konsep (NCTM, 2000). Jadi secara umum dapat dikatakan bahwa kemampuan generalisasi seseorang dapat diidentifikasi saat menyelesaikan masalah pola.

Pola adalah barisan bilangan yang suku-sukunya dapat diprediksi (Bishop, 2000; Billings, Tiedt, \& Slater, 2007; Hourigan \& Leavy, 2015; Setiawan, Purwanto, Parta, \& Sisworo, 2020). Bishop (2000) mendefinisikan pola bilangan sebagai barisan bilangan di mana ada aturan yang terdefinisi dengan baik untuk menghitung setiap bilangan dari bilangan sebelumnya atau dari posisi barisannya. Pola bilangan atau objek yang berubah dari satu suku ke suku berikutnya dengan cara yang dapat diprediksi (Billings, Tiedt, \& Slater, 2007). Berdasarkan representasinya, suku-suku dari pola bilangan dapat dinyatakan secara gambar yang dapat berupa gambar geometris. Pola geometris membentuk suatu pola, dimana gambar berikutnya diperoleh dari gambar sebelumnya dengan prosedur yang terdefinisi dengan baik (Bishop, 2000). Pola geometris dalam penelitian ini adalah pola linier. Pola linier adalah pola yang memiliki beda pertama dari suku-sukunya adalah konstan (Setiawan, 2019; Setiawan, Purwanto, Parta, \& Sisworo, 2020).

Penelitian tentang generalisasi pola linier telah banyak dilakukan. Misalnya hasil penelitian Lannin, Barker, dan Townsend (2006) menunjukkan bahwa salah satu yang mempengaruhi penggunaan strategi generalisasi pola linier adalah masalah pola linier dalam bentuk gambar. Hal ini dikarenakan bahwa pada saat situasi masalah berbentuk gambar, maka ada kemungkinan siswa memiliki keterbatasan persepsi dalam melihat situasi masalah yang menyebabkan siswa menggunakan strategi generalisasi yang tidak efisien atau kesalahan generalisasi. Lebih lanjut Lannin, Barker, dan Townsend (2006) merekomendasikan untuk memeriksa kesalahan-kesalahan siswa dalam menggeneralisasi pola linier. Karena hasil penelitian yang berupa kesalahan siswa dapat digunakan sebagai dasar pembelajaran untuk meningkatkan pemahaman siswa tentang generalisasi pola linier.

Hasil penelitian Barbosa, Palhares, dan Vale (2007) menunjukkan bahwa kecenderungan siswa untuk memanipulasi bilangan saja dapat berkonstribusi untuk meningkatkan kesulitan dalam menemukan pola yang dimaksud. Hasil penelitian Barbosa, Palhares, dan Vale (2007) juga menunjukkan bahwa beberapa barisan ditafsirkan sebagai pola berulang baik pada konteks visual maupun numerik. Hasil penelitian Hill, Lannin, dan Garderen (2015) menunjukkan bahwa kesulitan siswa dalam upaya menggeneralisasi antara lain: (a) kesulitan memperhatikan fitur umum di setiap representasi, masalah, dan situasi; (b) kesulitan untuk menerapkan ide-ide matematis untuk 
representasi, masalah, dan situasi baru. Akibat dari kesulitan-kesulitan ini, maka siswa akan melakukan kesalahan dalam generalisasi pola linier. Sebagai penelitian lanjutan dari penelitian sebelumnya (Lannin, Barker, \& Townsend, 2006; Barbosa, Palhares, \& Vale, 2007; Hill, Lannin, \& Garderen, 2015), maka penelitian ini bertujuan untuk menganalisis kesalahan siswa dalam menggeneralisasi pola linier. Perbedaan penelitian ini dengan penelitian sebelumnya adalah, jika penelitian sebelumnya (Lannin, Barker, \& Townsend, 2006; Barbosa, Palhares, \& Vale, 2007; Hill, Lannin, \& Garderen, 2015) fokus pada kesulitan siswa, maka penelitian ini fokus pada kesalahan siswa yang merupakan akibat dari kesulitan siswa dalam menggeneralisasi pola linier.

Manfaat penelitian tentang kesalahan siswa adalah dapat mengetahui sejauh mana pemahaman siswa terhadap materi tertentu (Ball \& Friel, 1991). Salah satu tujuan diskusi di kelas untuk mengungkap kesalahpahaman tentang matematika yang dibawa siswa ke kelas (Ball, 1993). Kesalahan siswa dapat mendorong keterlibatan siswa dalam diskusi matematika (Borasi, 1994). Diskusi tentang kesalahan-kesalahan dapat menyebabkan pencapaian yang lebih baik di kalangan siswa dalam matematika (Kazemi, 1998). Para peneliti melihat kesalahan sebagai sumber daya untuk mempromosikan pembelajaran dan bukan hanya sekedar alat diagnosis (Schleppenbach, Flevares, \& Sims, 2007). Kemampuan untuk mendiagnosis kesalahan siswa adalah salah satu kriteria untuk mendapatkan wawasan tentang pengetahuan matematika baik guru maupun siswa (Shabanifar \& Konyalioglu, 2013). Oleh karena itu, penelitian ini bertujuan untuk memperoleh gambaran kesalahan siswa dalam menggeneralisasi pola linier.

\section{Metode}

Penelitian ini adalah penelitian kualitatif deskriptif dengan pendekatan studi kasus terhadap 4 siswa kelas VIII SMP yang melakukan kesalahan dalam menyelesaikan masalah pola linier. Penelitian ini dilakukan di salah satu Sekolah Menengah Pertama Negeri di Kabupaten Lumajang. Prosedur pemilihan subjek penelitian dilakukan tiga langkah. Langkah pertama adalah meminta 54 siswa kelas VIII SMP untuk menyelesaikan soal pola linier. Langkah kedua adalah mengoreksi jawaban siswa berdasarkan jawaban benar dan salah. Dari 54 siswa yang menyelesaikan soal pola linier, diperoleh 15 siswa mengalami kesalahan generalisasi. Langkah ketiga adalah mengkategorikan kesalahan siswa dalam menggeneralisasi pola linier. Dari 15 siswa tersebut diperoleh: 6 siswa menulis generalisasi yang sama dari dua soal yang berbeda tanpa mengidentifikasi suku-sukunya (dari 6 siswa ini dipilih 1 siswa sebagai subjek pertama); 4 siswa menulis pola linier dalam bentuk pola kuadratik (setelah dikonfirmasi, kesalahan siswa disebabkan karena 
menuliskan $n+n$ dengan $n^{2}$, sehingga tidak dipilih sebagai subjek); 2 siswa menulis pola linier dalam bentuk $U_{n}=n+b$ (dari 2 siswa dipilih 1 siswa untuk menjadi subjek kedua). 1 siswa tidak menulis rumus generalisasinya (siswa ini tidak dijadikan subjek, karena saat dikonfirmasi siswa mengatakan sulit); 1 siswa menulis generalisasi setiap suku-sukunya (subjek ketiga); dan 1 siswa menulis generalisasi dalam bentuk deret (subjek keempat). Jadi total subjek penelitian ini ada 4 subjek.

Instrumen penelitian menggunakan soal tes representasi visual yang terdiri dari dua soal generalisasi pola linier dalam bentuk dimensi dua dan dimensi tiga yang dapat dilihat pada Tabel 1. Peneliti menggunakan soal bentuk visual didasarkan hasil penelitian Lannin, Barker, dan Townsend (2006) yang menunjukkan bahwa gambaran visual juga mempengaruhi pemilihan dan penggunaan strategi generalisasi. Selain itu, kelebihan pola geometris adalah memfasilitasi pendekatan pemecahan masalah yang memiliki potensi untuk meningkatkan tantangan siswa (Hourigan \& Leavy, 2015).

Tabel 1. Soal Generalisasi Pola Linier

\begin{tabular}{cl}
\hline No. & Soal \\
\hline 1. & Perhatikan Pola Berikut.
\end{tabular}

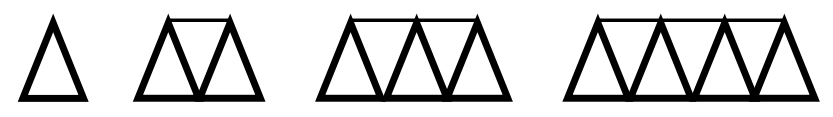

Tentukan:

a. Banyaknya segitiga pada suku ke-5 sampai ke-7! Tulislah cara Anda!

b. Rumus total segitiga pada suku ke- $n$ ! tulislah cara Anda!

c. Banyaknya segitiga pada suku ke-38! Tulislah cara Anda!

2. Perhatikan Pola Berikut.
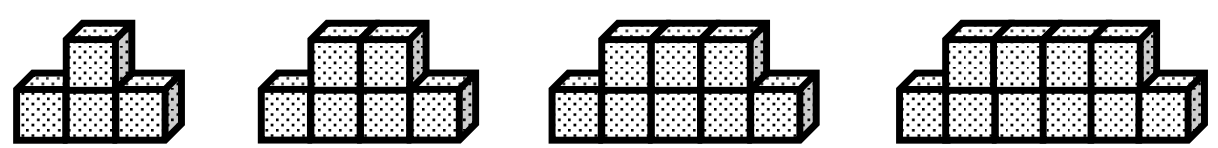

Tentukan:

a. Banyaknya kubus pada suku ke-5 sampai ke-7! Tulislah cara Anda!

b. Rumus banyaknya kubus pada suku ke-n! Tulislah cara Anda!

c. Banyaknya kubus pada suku ke-74! Tulislah cara Anda!

Tabel 1 menunjukan bahwa soal pertama menggunakan representasi berupa bangun segitiga dan soal kedua menggunakan representasi kubus. Kedua soal merupakan pola linier yang memiliki beda sama. Jika siswa tidak menganalisis lebih lanjut tentang perbedaan dari soal, maka siswa akan 
terjebak ke dalam generalisasi yang berlebihan (overgeneralization) dari kedua soal, sehingga siswa mengatakan bahwa kedua soal memiliki rumus suku ke$n$ yang sama. Tes ini bertujuan untuk melihat bagaimana kemampuan siswa ketika melakukan pencarian pola linier. Penerapan instrumen ini memungkinkan untuk mengumpulkan beberapa data awal tentang kesalahan dan kesulitan yang paling umum.

Analisis data hasil pekerjaan siswa dalam menyelesaikan soal generalisasi pola linier dilakukan dengan langkah-langkah: (1) mengelompokkan hasil generalisasi berdasarkan jawaban benar dan salah. (2) mengelompokkan jawaban yang salah berdasarkan kesamaan hasil generalisasi. (3) menganalisis secara deskriptif dari kesalahan generalisasi dengan mangkategorikan kesalahan generalisasi ke dalam dua bentuk kesalahan, yaitu overgeneralisasi dan overspesialisasi (Ashlock, 2006). Overgeneralisasi adalah terburu-buru mengambil kesimpulan sebelum memiliki data yang cukup (Ashlock, 2006), atau dengan kata lain overgeneralisasi adalah membuat generalisasi berdasarkan bukti yang tidak cukup. Sedangkan overspesialisasi adalah prosedur yang dihasilkan dibatasi secara tidak tepat (Ashlock, 2006). Berdasarkan pendapat tersebut, peneliti menganalisis kesalahan pekerjaan siswa dalam menggeneralisasi pola linier yang berupa overgeneralisasi adalah berdasarkan kesimpulan yang dibuat oleh siswa, sedangkan overspesialisasi berdasarkan prosedur yang digunakan oleh siswa. (4) melakukan wawancara untuk mengklarifikasi temuan dari hasil analisis dari kesalahan-kesalahan generalisasi yang dilakukan siswa dan untuk mengetahui penyebab kesalahan yang dilakukan oleh siswa.

\section{Hasil dan Pembahasan}

Hasil menunjukan siswa lebih banyak mengalami kesalahan overgeneralisasi daripada kesalahan overspesialisasi dalam menggeneralisasi pola linier. Masing-masing kesalahan ini dibahas berikut.

\section{Overgeneralisasi}

Kesalahan siswa yang termasuk overgeneralisasi yaitu : (1) menulis rumus suku ke- $n$ yang sama saat melihat dua pola linier memiliki beda sama, tetapi suku-sukunya berbeda; (2) menulis rumus suku ke- $n$ dari pola linier dalam bentuk $U_{n}=n+b$; dan (3) menulis rumus suku ke- $n$ secara khusus untuk setiap suku.

\section{Menulis Rumus Suku Ke-n yang Sama dari Dua Pola Linier yang Berbeda}

Subjek pertama (S1) menulis hasil generalisasi berupa suku ke- $n$ yang sama hanya didasarkan kedua masalah pola linier (Tabel 1) memiliki beda yang 
sama. Kesalahan ini termasuk kesalahan overgeneralisasi, karena subjek hanya melihat beda tanpa mengidentifikasi suku-suku dari kedua masalah pola linier tersebut. Hasil subjek menulis rumus suku ke- $n$ yang sama dapat dilihat pada Gambar 1.

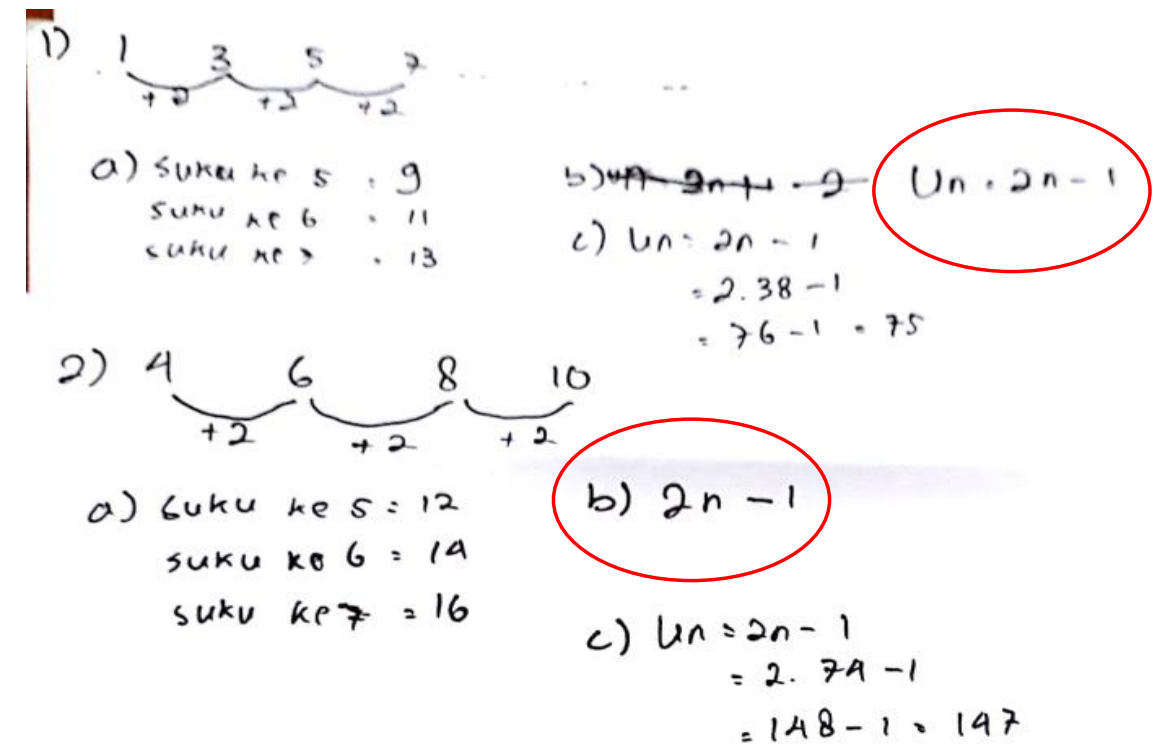

Gambar 1. Jawaban Subjek Menulis Generalisasi yang Sama

Gambar 1 menunjukan bahwa subjek mengubah gambar ke dalam pola bilangan. Subjek menemukan suku ke-5, suku ke-6, dan suku ke-7 dengan menggunakan beda. Subjek menentukan rumus suku ke- $n$ dari pola linier dengan menggunakan beda, yaitu suku kedua dikurangi suku pertama, sehingga diperoleh beda dari soal pertama adalah 2. Dengan menggunakan beda, subjek menentukan rumus suku ke- $n$ dari pola linier pertama dengan benar, yaitu $U_{n}=2 n-1$. Untuk menyelesaikan masalah pola linier kedua, subjek juga menggunakan beda. Masalah pola linier kedua memiliki beda yang sama dengan pola linier pertama. Subjek menuliskan rumus suku ke- $n$ yang sama dari masalah pola linier kedua dengan pola linier pertama. Alasan subjek menuliskan rumus suku ke- $n$ yang sama ini dapat diketahui dari cuplikan wawancara berikut.

\footnotetext{
Peneliti : Dari mana Anda memperoleh rumus $U_{n}=2 n-1$ pada soal nomor 1 ?

S1 : $2 n$ diperoleh dari beda pak. -1 diperoleh dari pola. Misalkan 2(1)=2, maka dikurangi 1 agar menjadi 1; 2(2)=4, maka dikurangi 1 agar menjadi 3, dan seterusnya. Sehingga saya menulis $U_{n}=2 n-1$.

Peneliti : Dari mana Anda memperoleh rumus $U_{n}=2 n-1$ pada soal nomor 2?

S1 : Karena soal nomor 2 memiliki beda yang sama dengan soal nomor 1 , jadi rumusnya sama pak.
} 
Hasil wawancara menunjukan bahwa untuk memperoleh rumus suku ke- $n$ pola linier dari soal pertama dilakukan dengan mencari beda, dan subjek menuliskan dengan $2 n$. Kemudian dengan menggunakan $2 n$, subjek mencari pola yang terbentuk dari pola bilangan. Setelah menemukan pola, subjek dapat menggeneralisasi dengan benar dari pola linier pertama. Hasil generalisasi pada soal pertama ditulis kembali oleh subjek sebagai hasil generalisasi dari pola linier yang kedua. Pada akhirnya subjek mengalami kesalahan overgeneralisasi pada masalah pola linier kedua.

Ada tiga penyebab kesalahan menulis generalisasi pola linier yang sama saat menyelesaikan dua soal memiliki beda sama, tetapi suku-sukunya berbeda. Pertama, subjek fokus pada mengubah gambar menjadi bentuk bilangan. Dalam hal ini subjek tidak melihat fitur-fitur dari gambar yang dapat digunakan untuk merumuskan hasil generalisasi. Hasil penelitian Hill, Lannin, dan Garderen (2015) menunjukkan bahwa salah satu kesulitan siswa dalam upaya menggeneralisasi adalah kesulitan memperhatikan fitur-fitur yang umum di setiap representasi, situasi, atau masalah. Kedua, kesalahan ini disebabkan oleh subjek yang hanya mengidentifikasi kesamaan dari dua soal (yaitu beda yang sama), tanpa mengidentifikasi perbedaan dari dua soal (suku-sukunya). Hal ini sesuai dengan hasil penelitian Hill, Lannin, dan Garderen (2015) yang menunjukkan bahwa penting untuk melihat kesamaan di dua kasus yang berbeda, peneliti menambahkan bahwa juga penting melihat perbedaan dari dua kasus, agar tidak terjadi overgeneralisasi. Penyebab ketiga dari kesalahan ini adalah subjek fokus pada pola yang terbentuk dari pola linier. Hasil penelitian Ellis (2011) menunjukkan bahwa fokus pada hubungan antara kuantitas (bukan pada pola atau prosedur saja) lebih memungkinkan untuk mendukung generalisasi yang kuat.

\section{Menulis hasil generalisasi dalam bentuk $\boldsymbol{U}_{\boldsymbol{n}}=\boldsymbol{n}+\boldsymbol{b}$}

Subjek kedua (S2) mengalami overgeneralisasi dengan menuliskan rumus generalisasi pola linier dalam bentuk $U_{n}=n+b$. Jawaban subjek kedua ini dapat dilihat dalam Gambar 2.

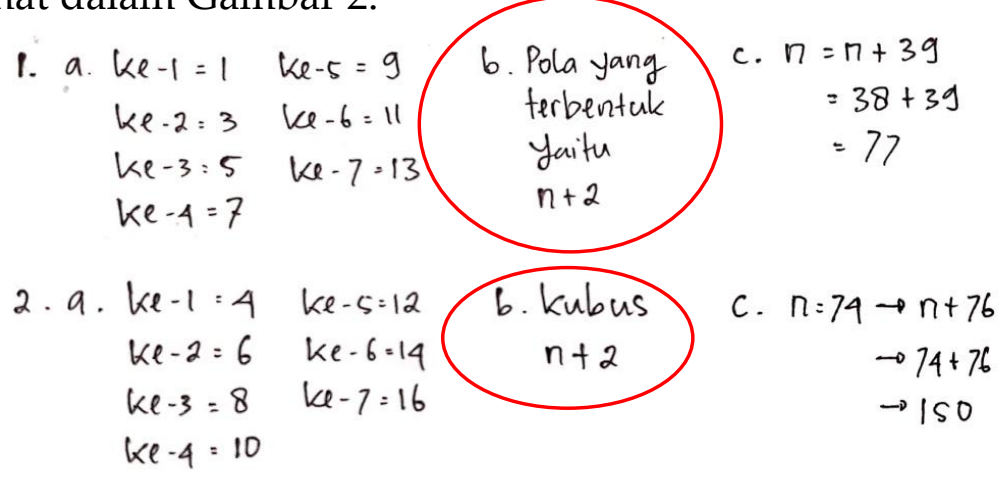

Gambar 2. Kesalahan Generalisasi dalam bentuk $U_{n}=n+b$ 
Gambar 2 menunjukan bahwa subjek juga mengubah representasi geometris ke dalam pola bilangan. Kemudian subjek menggunakan beda untuk menemukan suku ke-5, suku ke-6, dan suku ke-7. Selanjutnya, subjek menulis rumus generalisasi yang sama dari pola linier pertama dan kedua, yaitu $U_{n}=$ $n+2$. Cara subjek memperoleh rumus generalisasi pola linier ini dapat diketahui dari cuplikan wawancara sebagai berikut.

$\begin{array}{ll}\text { Peneliti } & : \text { Dari mana Anda memperoleh rumus } U_{n}=n+2 \text { pada soal nomor satu? } \\ \text { S2 } & : \text { nadalah suku pertama pak dan } 2 \text { adalah beda. } \\ \text { Peneliti } & : \text { Mengapa Anda menulis rumus generalisasinya dalam bentuk } U_{n}=n+2 ? \\ \text { S2 } & : \text { Iya pak, karena } 1+2=3 \text {. Jadi saya menulis rumusnya } n+2 . \\ \text { Peneliti } & : \text { Dari mana Anda memperoleh suku ke-38 pada soal nomor satu? } \\ \text { S2 } & : \text { Dari } 38+39 \text { pak, karena } 1+2=3 \text {. dan saya menulisnya } 38+39=77 . \\ \text { Peneliti } & : \text { Dari mana Anda memperoleh rumus } U_{n}=n+2 \text { pada soal nomor dua? } \\ \text { S2 } & : \text { Karena bedanya sama pak dengan nomor satu. } \\ \text { Peneliti } & : \text { Dari mana Anda memperoleh suku ke-74 dari soal nomor dua? } \\ \text { S2 } & : \text { Dari } 74+76 \text { pak, karena } 4+2=6 \text {. Jadi } 74 \text { saya tambahkan } 2 \text { pak, (siswa menulis } \\ & \end{array}$

Dari hasil wawancara diketahui bahwa arti dari rumus $n+2$ adalah $n$ merupakan suku pertama dan 2 adalah beda yang digunakan untuk menentukan suku ke-2. Kemudian subjek menuliskan rumus generalisasinya dalam bentuk $U_{n}=n+2$. Karena untuk mendapatkan suku ketiga diperoleh dari $1+2=3$, maka subjek menentukan suku ke-38 dengan cara yang sama, yaitu $38+39=77$. Cara ini dilakukan oleh subjek yang hanya melihat suku pertama dan beda untuk menghasilkan suku kedua, dan kemudian digunakan untuk menemukan suku ke-38. Subjek menulis rumus generalisasi yang sama pada soal nomor dua, karena memiliki beda yang sama dengan soal pertama, yaitu $U_{n}=n+2$.

Penyebab kesalahan subjek dalam menuliskan rumus generalisasi ada dua. Pertama, subjek kesulitan untuk menemukan rumus generalisasinya, sehingga subjek menuliskan dengan rumus $U_{n}=n+2$. Kedua, perhatian subjek hanya tertuju pada suku pertama dan beda. Ini diketahui dari wawancara saat subjek mengatakan $n$ adalah suku pertama dan 2 adalah beda. Ini merupakan faktor kognitif yang mempengaruhi strategi generalisasi subjek, yaitu perhatian dan kesadaran (Rivera, 2015). Hasil penelitian Rivera (2015) menunjukkan bahwa saat menyelesaikan soal generalisasi pola terdapat dua pemrosesan, yaitu pemrosesan berurutan dan pemrosesan selektif. Pemrosesan berurutan dilakukan secara induktif (Rivera, 2015) yang pada akhirnya siswa dapat menggeneralisasi pola dengan benar. Sedangkan pemrosesan selektif adalah hanya menggunakan tahapan tertentu dari pola 
berkembang untuk menggeneralisasi pola. Kesalahan menuliskan rumus generalisasi dalam bentuk rumus $U_{n}=n+b$ disebabkan karena pemrosesan selektif, yaitu hanya melihat suku pertama, beda dan suku kedua.

\section{Menulis rumus secara khusus untuk setiap suku}

Subjek ketiga (S3) yang mengalami overgeneralisasi yaitu subjek terburu-buru menulis rumus generalisasi tanpa menemukan kesamaan dari tiap-tiap suku. Akibatnya subjek tidak menuliskan rumus umum yang berlaku untuk suku ke- $n$. Hasil pekerjaan subjek yang menulis rumus untuk setiap suku dapat dilihat pada Gambar 3.

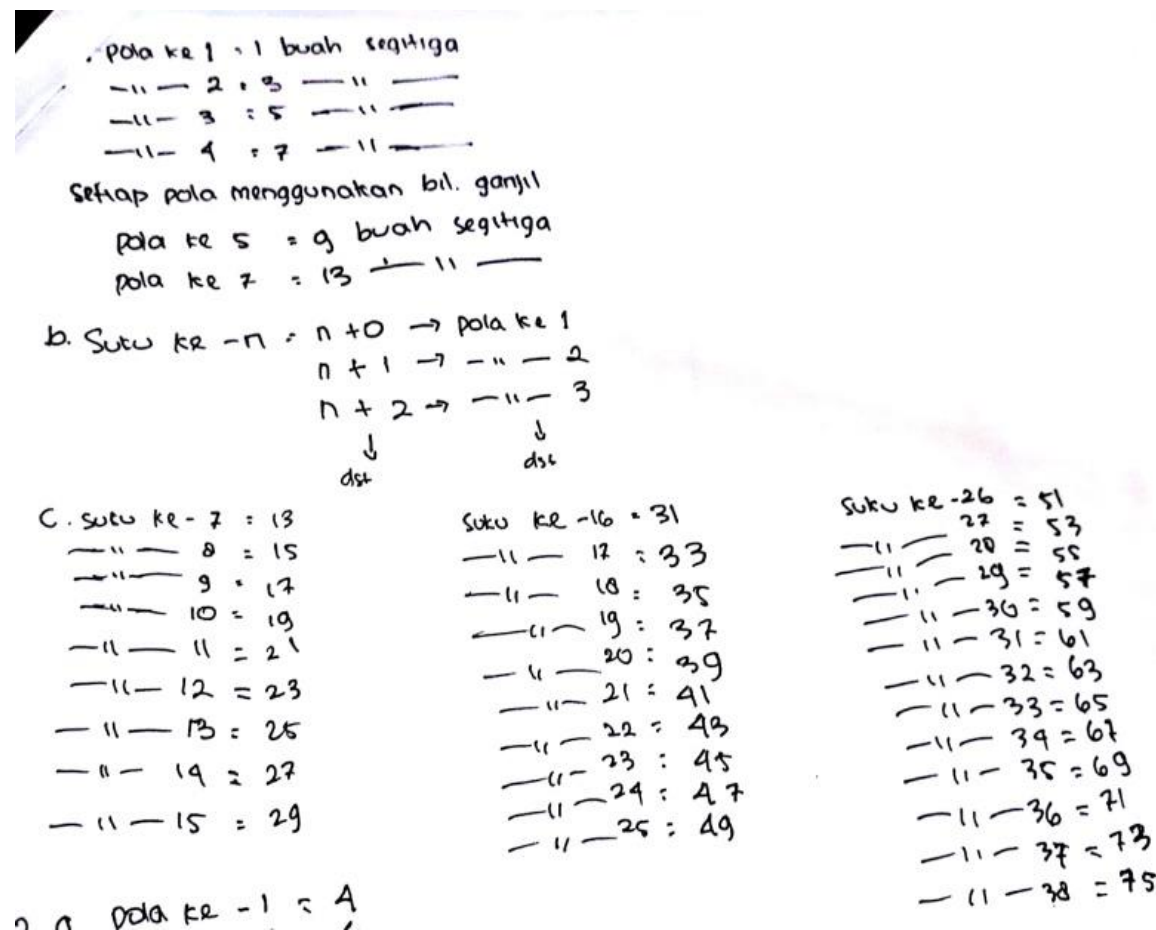

Gambar 3. Subjek Menuliskan Rumus Secara Khusus untuk Setiap Suku

Gambar 3 menunjukan bahwa subjek memulai menggeneralisasi dengan menemukan pola bilangan, subjek menuliskan bahwa setiap pola menggunakan bilangan ganjil. Setelah menemukan pola bilangan ganjil, subjek membuat pola untuk masing-masing suku. Suku pertama polanya adalah $n+0$, suku ke-2 polanya adalah $n+1$, suku ke-3 polanya adalah $n+$ 2 , dan seterusnya. Cara subjek memperoleh rumus suku ke- $n$ ini dapat diketahui dari cuplikan hasil wawancara berikut ini.

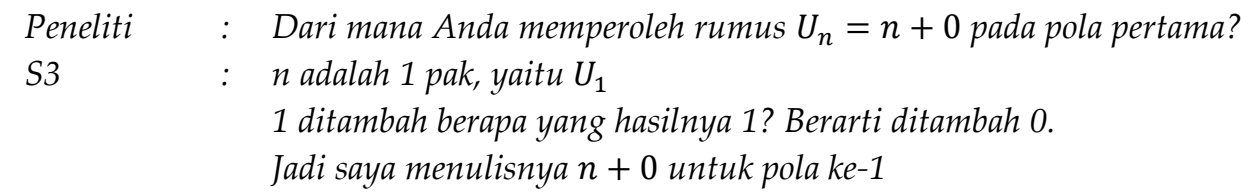




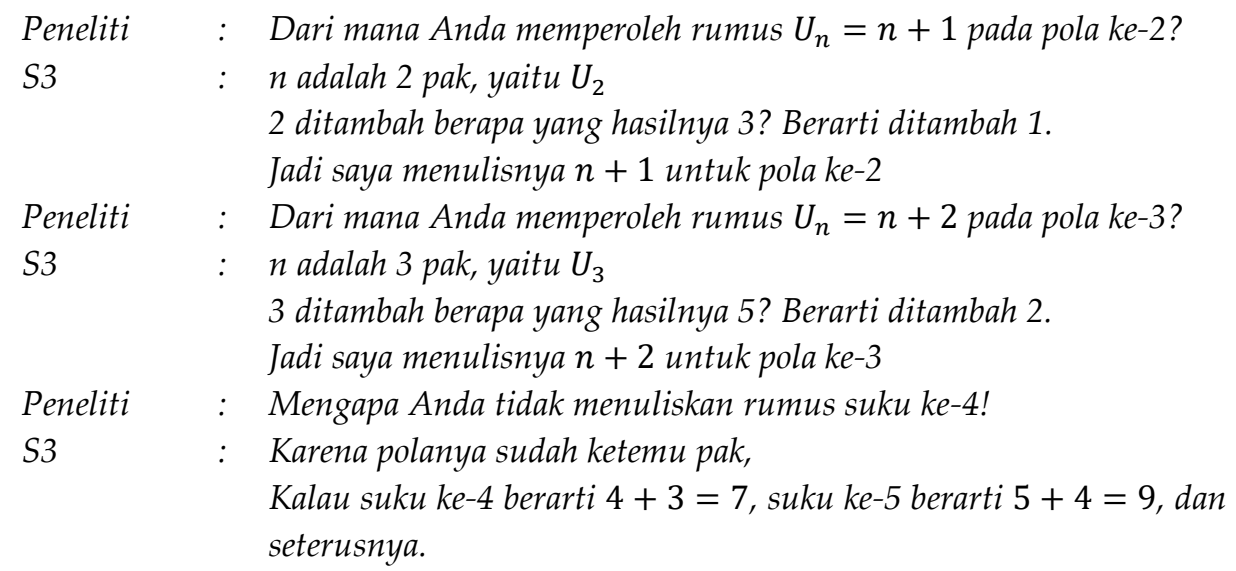

Dari cuplikan hasil wawancara diketahui bahwa subjek menulis rumus pola pertama $U_{n}=n+0$ dari suku pertama, yaitu $1+0=1$, kemudian untuk memperoleh rumus suku kedua adalah $2+1=3$, dan untuk memperoleh suku ketiga adalah $3+2=5$. Subjek tidak menuliskan rumus suku keempat, dikarenakan subjek telah menemukan pola secara rekursif.

Penyebab kesalahan subjek dalam menuliskan rumus generalisasi untuk setiap suku ada dua, yaitu: Pertama, subjek fokus pada suku pertama dengan cara mencoba-coba, yaitu subjek mencoba $1+0=1$, kemudian subjek mencoba menentukan suku kedua dengan cara $2+1=3$, dan mencoba menemukan suku ketiga dengan cara $3+2=5$, dan akhirnya subjek mengatakan menemukan pola dengan cara $n$ ditambah bilangan yang berurutan dimulai dari 0 , misalkan suku ke-4 berarti $4+3=7$, suku kelima berarti $5+4=9$, dan seterusnya. Ini artinya perhatian subjek hanya tertuju bagaimana mendapatkan suku pertama, kedua, dan ketiga, kemudian subjek secara langsung membuat kesimpulan. Pemrosesan ini termasuk pemrosesan selektif (Rivera, 2015) yaitu hanya menggunakan pola suku pertama, pola suku kedua, dan pola suku ketiga. Kedua, subjek tidak melihat kembali kesamaan dari masing-masing pola pertama, pola kedua, dan pola ketiga, subjek dengan tergesah-gesah mengambil kesimpulan polanya dalam bentuk rekursif. Hasil penelitian (Setiawan, 2020a) menunjukkan bahwa siswa dengan kemampuan rendah memiliki asumsi yang tidak logis, yaitu tidak sesuai tahapan-tahapan penyelesaian masalah matematika.

\section{Overspesialisasi}

Hasil penelitian menunjukkan bahwa kesalahan yang termasuk overspesialisasi dalam menggeneralisasi pola linier adalah memberikan batasan istilah total sebagai deret, sehingga terjadi kesalahan dalam menuliskan suku ke- $n$ dalam bentuk deret. 


\section{Menulis generalisasi dalam bentuk deret}

Subjek keempat (S4) menulis hasil generalisasinya dalam bentuk deret berhingga. Ini termasuk kesalahan overspesialisasi, yaitu kesalahan dalam melakukan pembatasan istilah total yang diartikan oleh subjek sebagai deret, sehingga subjek menulis hasil generalisasi dalam bentuk deret. Hasil generalisasi subjek yang berupa deret dapat dilihat pada Gambar 4 .
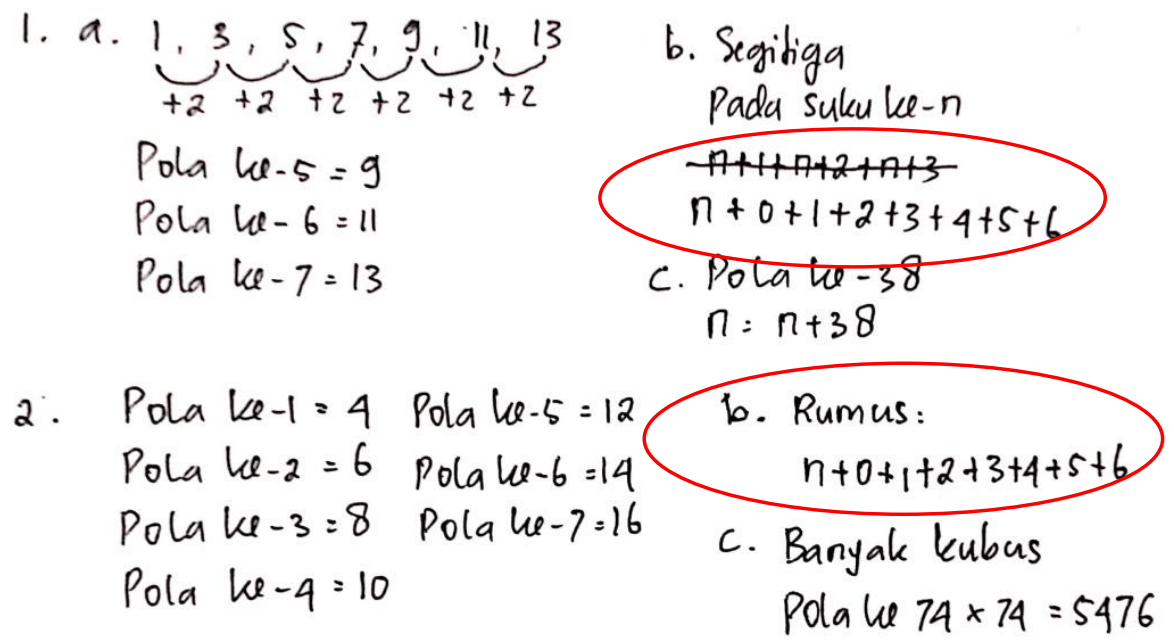

Gambar 4. Generalisasi Subjek yang Berupa Deret Berhingga

Gambar 4 menunjukan bahwa subjek pertama menentukan beda untuk mendapatkan suku kelima, suku keenam, dan suku ketujuh. Kemudian subjek menuliskan rumus generalisasi dalam bentuk $n+1+n+2+n+3$ (tetapi hasil ini dicoret oleh subjek) dan diganti dengan deret $n+0+1+2+3+4+$ $5+6$. Kemudian untuk menentukan suku ke-38 subjek menuliskan dengan $n+38$. Cara subjek menggeneralisasi soal ini dapat diketahui dari cuplikan hasil wawancara berikut ini.

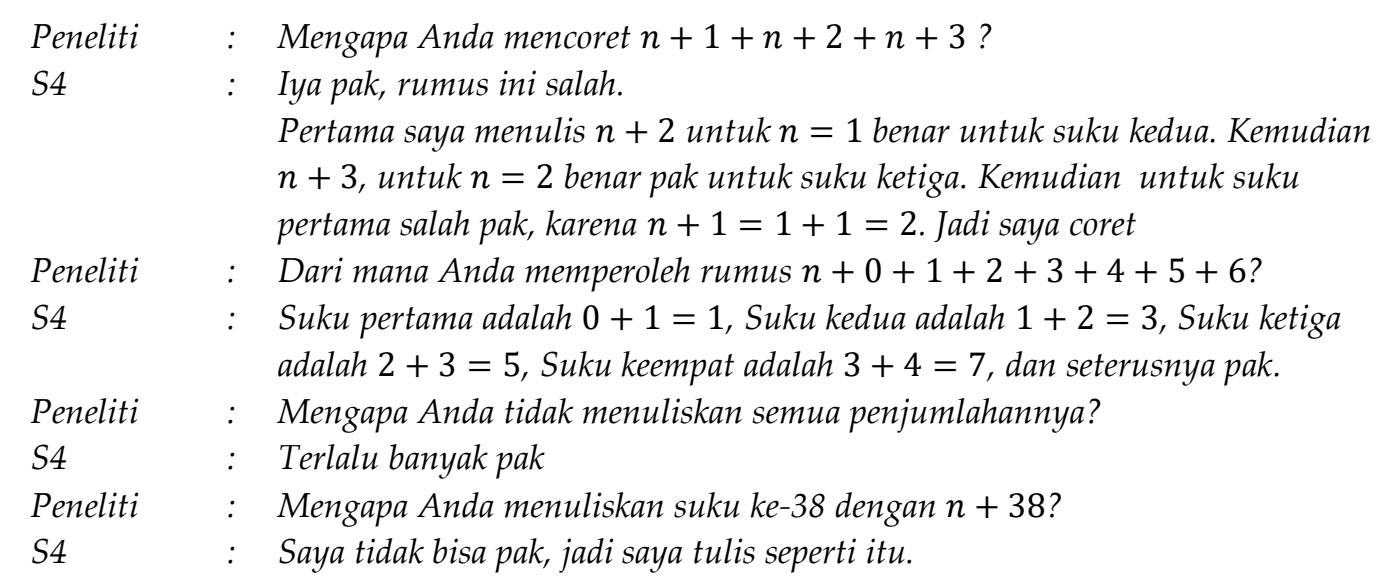


Dari hasil wawancara diperoleh penyebab kesalahan menuliskan rumus generalisasi dalam bentuk deret berhingga, yaitu subjek sudah memikirkan bentuk deret, tetapi rumus pertama salah dan kemudian subjek membenarkan rumus yang salah dengan tetap menggunakan deret.

Penyebab utama subjek menuliskan hasil generalisasi dalam bentuk deret adalah subjek sudah mulai memikirkan deret di awal menggeneralisasi pola. Ini berarti awal pemikiran merupakan hal penting yang akan mempengaruhi proses dan hasil generalisasi. Penyebab memikirkan deret ini dikarenakan persepsi subjek tentang istilah total segitiga suku ke- $n$ dengan penjumlahan. Hal ini sesuai dengan pendapat (Lannin, Barker, \& Townsend, 2006) yang mengatakan bahwa keterbatasan persepsi siswa dari situasi masalah dapat menyebabkan siswa untuk terus menggunakan strategi yang tidak efisien atau kesalahan generalisasi. Jadi penyebab kesalahan generalisasi ini adalah membatasi persepsi. Ini juga penting untuk menekankan pemahaman konsep antara deret dan barisan bilangan. Hal ini sesuai hasil penelitian yang menunjukkan bahwa dalam pembelajaran matematika penting untuk menekankan pemahaman konsep (Setiawan, 2020c, 2020b; Setiawan \& Mustangin, 2020; Setiawan \& Syaifuddin, 2020).

\section{Simpulan}

Diperoleh kesimpulan bahwa kesalahan saat menggeneralisasi pola linier secara umum terbagi menjadi dua, yaitu overgeneralisasi dan overspesialisasi. Kesalahan berupa overgeneralisasi ada tiga. Pertama, subjek menulis rumus generalisasi yang sama saat melihat dua soal yang memiliki beda sama, tetapi suku-sukunya berbeda. Ada tiga penyebab kesalahan ini, yaitu: (a) subjek tidak melihat fitur-fitur dari gambar yang dapat digunakan untuk menggeneralisasi pola linier; (b) subjek hanya mengidentifikasi kesamaan dari dua soal (yaitu beda yang sama), tanpa mengidentifikasi perbedaan dari dua soal (yaitu suku-sukunya); (c) subjek fokus pada mencari pola daripada memahami hubungan kuantitas. Kedua, subjek menulis rumus generalisasi pola linier dalam bentuk $U_{n}=n+b$. Ada dua penyebab kesalahan ini, yaitu: (a) subjek merasa kesulitan untuk menentukan rumus generalisasinya; (b) perhatian subjek hanya tertuju pada suku pertama dan beda, ini dikarenakan pemrosesan secara selektif. Ketiga, menulis rumus untuk setiap suku. Ada dua penyebab kesalahan ini, yaitu: (a) subjek fokus pada suku pertama, yaitu menemukan rumus untuk suku pertama dengan cara mencoba-coba; (b) subjek tidak melihat kembali dari masing-masing pola, sehingga tergesahgesah mengambil kesimpulan. Kesalahan yang berupa overspesialisasi yaitu subjek menuliskan hasil generalisasi dalam bentuk deret. Penyebab kesalahan ini adalah subjek sudah mulai memikirkan deret di awal menggeneralisasi 
pola, penyebab memikirkan deret adalah persepsi subjek terhadap total segitiga suku ke- $n$ yang merupakan penjumlahan.

Hasil penelitian ini dapat dijadikan sebagai upaya untuk mengurangi kesalahan-kesalahan generalisasi pola linier. Untuk menghindari overgeneralisasi adalah dengan cara: (1) siswa diminta untuk melihat fiturfitur dari gambar yang dapat digunakan untuk menggeneralisasi pola linier; (2) ketika menyelesaikan dua soal, tidak hanya mengidentifikasi kesamaan saja, tetapi siswa juga harus mengetahui perbedaan kedua soal; (3) siswa tidak hanya melakukan pemrosesan selektif, tetapi juga harus melakukan pemrosesan berurutan secara induktif. Rekomendasi pembelajaran untuk menghindari kesalahan overspesialisasi adalah guru lebih menekankan kepada makna dari istilah-istilah yang ada pada pola linier. Rekomendasi penelitian lanjutan adalah menganalisis kesalahan dengan tugas generalisasi yang berbeda.

\section{Daftar Pustaka}

Ashlock, R. B. (2006). Error Patterns in Computation: Using Error Patterns to Improve Instruction (Ninth Edition). Columbus, Ohio: Pearson Merrill Prentice Hall.

Ball, D. L. (1993). With an Eye on the Mathematical Horizon: Dilemmas of Teaching Elementary School Mathematics. The Elementary School Journal, 93(4), 373-397.

Ball, D. L., \& Friel, S. N. (1991). Implementing The Professional Standards for Teaching Mathematics: What's All This Talk About "Discourse"? The Arithmetic Teacher, 39(3), 4448.

Barbosa, A., Palhares, P., \& Vale, I. (2007). Patterns and Generalization: The Influence of Visual Strategies. In Proceedings of the Fifth Congress of the European Society for Research in Mathematics Education (pp. 844-851).

Billings, E. M. H., Tiedt, T. L., \& Slater, L. H. (2007). Algebraic Thinking Pictorial Growth Patterns. Teaching Children Mathematics, 14(5), 302-308.

Bishop, J. (2000). Linear Geometric Number Patterns: Middle School Students' Strategies. Mathematics Education Research Journal, 12(2), 107-126.

Borasi, R. (1994). Capitalizing on Errors as "Springboards for Inquiry": A Teaching Experiment. Journal for Research in Mathematics Education, 25(2), 166-208.

Chua, B. L., \& Hoyles, C. (2014). Generalisation of Linear Figural Patterns in Secondary School Mathematics. The Mathematics Educator, 15(2), 1-30.

Ellis, A. B. (2011). Generalizing-Promoting Actions: How Classroom Collaborations Can Support Students' Mathematical Generalizations. Journal for Research in Mathematics Education, 42(4), 308-345.

Ellis, A., Tillema, E., Lockwood, E., \& Moore, K. (2017). Generalization Across Domains: The Relating-Forming-Extending Generalization Framework. In J. Galindo, E., \& Newton (Ed.), Proceedings of the 39th annual meeting of the North American Chapter of the International Group for the Psychology of Mathematics Education (pp. 677-684). Indianapolis, IN: Hoosier Association of Mathematics Teacher Educators.

Hill, T., Lannin, J., \& Garderen, D. V. (2015). Promoting and Assessing Mathematical Generalising. AMPC, 20(4), 3-8.

Hourigan, M., \& Leavy, A. (2015). Geometric Growing Patterns What's The Rule? APMC, 
20(4), 31-40.

Jureczko, J. (2017). The Strategies of Using a Special Kind of Number Patterns in Different Stages of Education. Educational Research and Reviews, 12(12), 643-652.

Kazemi. (1998). Discourse that Promotes Conceptual Understanding. European Physical Education Review, 8(3), 191-204.

Lannin, J., Barker, D., \& Townsend, B. (2006). Algebraic Generalisation Strategies : Factors Influencing Student Strategy Selection Prior Research on Generalisation. Mathematics Education Research Journal, 18(3), 3-28.

NCTM. (2000). Principles and Standards for School Mathematics. United States of America: The National Council of Teachers of Mathematics, Inc.

Rivera, F. (2015). The Distributed Nature of Pattern Generalization. PNA, 9(3), 165-191.

Schleppenbach, M., Flevares, L. M., \& Sims, L. M. (2007). Teachers' Responses to Student Mistakes In Chinese And U.S. Mathematics Classrooms. The Elementary School Journal, 108(2), 131-147.

Setiawan, Y. E. (2019). Pembelajaran Pola Bilangan. Lumajang: CV. Al-Mukmin Yes.

Setiawan, Y. E. (2020a). Analisis Kemampuan Siswa dalam Pembuktian Kesebangunan Dua Segitiga. Al-Khwarizmi: Jurnal Pendidikan Matematika Dan Ilmu Pengetahuan Alam, 8(1), 2540.

Setiawan, Y. E. (2020b). Analisis Kesalahan Siswa dalam Menilai Kebenaran Suatu Pernyataan. Jurnal Didaktik Matematika, 7(1), 13-31.

Setiawan, Y. E. (2020c). The Thinking Process of Students Using Trial and Error Strategies in Generalizing Linear Patterns. Numerical: Jurnal Matematika Dan Pendidikan Matematika, 4(1), 1-12.

Setiawan, Y. E., \& Mustangin. (2020). Validitas Model Pembelajaran IDEA (Issue, Discussion, Establish, and Apply) untuk Meningkatkan Pemahaman Konsep. Jurnal Penelitian Pendidikan Dan Pengajaran Matematika, 6(1), 53-60.

Setiawan, Y. E., Purwanto, Parta, I. N., \& Sisworo. (2020). Generalization Strategy of Linear Patterns From Field-Dependent Cognitive Style. Journal on Mathematics Education, 11(1), 77-94.

Setiawan, Y. E., \& Syaifuddin. (2020). Peningkatan Kompetensi Profesionalitas Guru Melalui Pelatihan Desain Pembelajaran Peta Konsep. Jurnal Pengabdian Kepada Masyarakat, 26(3), 148-153.

Shabanifar, S., \& Konyalioglu, A. C. (2013). Mathematics Teachers' Approaches to Students' Possible Mistakes In Exponential And Square Root Number. International Journal of Academic Research, 5(6), 213-219.

Tanişli, D., \& Özdaş, A. (2009). The Strategies of Using the Generalizing Patterns of The Primary School 5 th Grade Students. Educational Sciences: Theory and Practice, 9(3), 14851497.

Tillema, E., \& Gatza, A. (2017). The Processes and Products of Students' Generalizing Activity. In E. Galindo \& J. Newton (Eds.), Proceedings of the 39th annual meeting of the North American Chapter of the International Group for the Psychology of Mathematics Education. (pp. 259-266). Indianapolis, IN: Hoosier Association of Mathematics Teacher Educators. 